\title{
The Creative Activity of National Intelligencia in the Creation of Kazakh Terminology
}

\author{
Shara Mazhitayeva ${ }^{1}, Z_{\text {Zhanat Rapisheva }}{ }^{1}, Z$ hanbyrbay Kagazbayev ${ }^{1}$, Kamshat Toleubayeva $^{1}$, Aitbay \\ Zhumagulov $^{1}$, Sagymbay Zhumagulov ${ }^{2} \&$ Nurbibi Smagulova $^{3}$ \\ ${ }^{1}$ Karaganda State University named after E. A. Buketov, Kazakhstan \\ ${ }^{2}$ The Euroasian National University named after L. N. Gumilev, Kazakhstan \\ ${ }^{3}$ Karaganda State Technical University, Kazakhstan \\ Correspondence: Shara Mazhitayeva, Karaganda State University named after E. A. Buketov, Kazakhstan. \\ E-mail: S_mazhit@mail.ru
}

Received: February 27, 2015

Accepted: April 26, 2015 Online Published: July 30, 2015

doi:10.5539/ass.v11n19p49

URL: http://dx.doi.org/10.5539/ass.v11n19p49

\begin{abstract}
The issues relating to the creating, formation, systematizing and putting in good order the terminology as a phenomenon is of vital importance for full-blended functioning of the Kazakh language in various fields of science. The present article focuses on the studying of factures that display the formation of scientific style and terminology at the beginning of XX century. It also emphasizes the rule of translation, first course book, and the usage of terms; characteristic features of scientific style, their special nature stage of formation and their development peculiarities. The study of Kazakh progressive-mind scholars' heritage who unsparingly contributed the functioning of the Kazakh language in science is very significant both for science and society.
\end{abstract}

Keywords: term, the use of terms, terminology, scientific terminology, scientific style, scientific language, Kazakh intelligentsia, the first course books

\section{Introduction}

The status of the literary language is closely connected with its functioning as the language of science. One of the ways of developing the Kazakh language as the language of science is first and foremost to define the scientific status of it. Second, to regulate constituent parts of terminological units. Third, to determine methods and techniques of defining the meaning of the term.

Scientific and terminological problems of scientific style and terminology have been investigated by D. S. Lotte (1969), G. O. Vinokur (1939), V. D. Petushkov (1972, pp. 102-116), A. A. Reformatsky (1968, pp. 103-125), O. I. Blinova (1981, pp. 45-58), V. P. Danilenko (1977), F. P. Sorokoletov (1976), B. N. Golovin (1973), O. V. Felde (2010, pp. 71-76), C. V. Grinyev (1993; 2008, p. 304), I. P. Galperin, V. V. Vinogradov, A. V. Superanskaya, etc. In the works of the XX- th century scholars V. M. Leychick (1989), S. D. Shelov (2011, pp. 7-18) the concept (term) is not considered as a separate element, but as a whole system. Topic problems of terminology in the XXI century were discussed in the learned works by S. L. Mishlanova (2003), V. A. Tatarinov (1995; 1996), M. N. Volodina (1997, pp. 217-222), etc.

The scientific language and its terminological issues in the Kazakh linguistics date back to the works by A. Baitursynov (2003, p. 208), Zh. Aimauytov (2005, p. 448), Kh. Dosmukhambeduly (1997, p. 176), K. Kemengerov, S. Zhienbayev, the burning topic of Kazakh national terminology was brought to a qualitative close by R. Syzdyk (2009, p. 518), A. Kaydarov (2008, p. 343), U. Aitbayev (1997, p. 240), Sh. Kurmanbayev (1999; 2008; 2014), Sh. Mazhitayeva (2000, p. 234; 2007; 2014). The importance of in-depth study of terminology in various fields of science defining their composition and structure giving the right definition in Kazakh linguistics has been especially emphasized by M. Moldazharov, S. Akayev, Sh. Bilyalov, K. Ayapbergenova, K. Kurkebayev, A. Konurova, A. Nurzhanova, S. Sarsenova, etc.

\section{Materials and Methods}

The main conclusions have been made on researching into the works by A. Baitursynov, Kh. Zhubanov, K. Kemengerov, T. Skonanov, Zh. Aimautov, Kh. Dosmukhamedov published in the twenties and thirties of the XX 
century translation and mass media sources of that time. Various methods such as comparison, confrontation, statistical analysis, synthesis, language and stylistic analysis have been applied in the present study.

\section{Results}

The range of social functions of the Kazakh language has broadened and stored up fresh energy since it gained official status. Therefore at the present state of social official status the formation a scientific language to a grant extent depends on the creating of scientific style and scientific terminology. Every era every stage of society development brings about innovations, it is the language a means that provides a new concept with a new name. A natural term enables spiritual progress, an indication of the development of science.

The main materials of scientific language (some researchers call them (backbone)) are the terms that can be defined as the word to be used in a definite field of science, the unity of specialist name (Lotte, 1969; Grinev, 1993, p. 304; 2008; Volodina, 1997, 2013, pp. 217-222).

(Kurmanbaiuly, 2008) The fact that scientific terminology was formed on the basis of public language cannot be denied. The creation of scientific terminology is the indication of the process that special fields of science can be treated as a separate sphere. Within the depths of civilization every sovereign and independent state possesses aspects of an honorary official language: "national language), (literary language), "scientific language), official language. Terminology is a constituent part of the language that can be renewed, changed in accordance with challenges of life on one hand, and be vigorous on the other hand. (Figure 1)

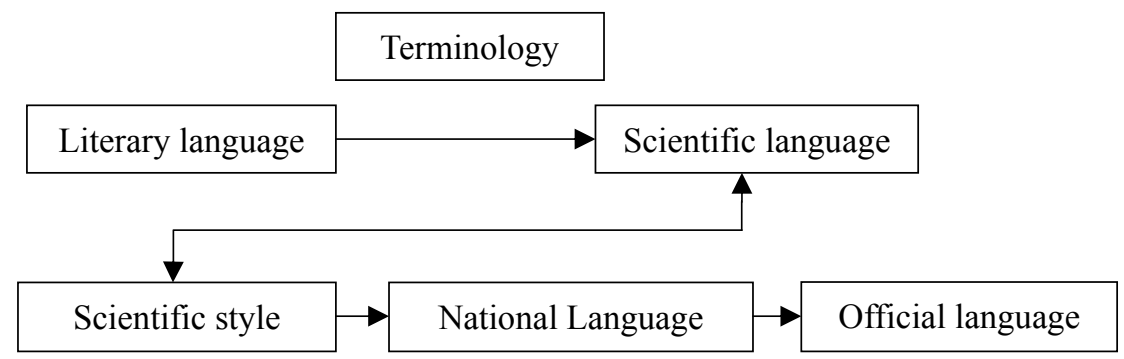

Figure 1. The concept "terminology" is closely connected with the above mentioned notions

In the course of study of the scientific terminology problem we have analyzed the first publications, course books, scientific works written in various fields of science. None the less, long ago before the printed matters have appeared there was a lexical layer bearing a relation to material and spiritual spheres of human life, social-economic, public relations, customs and traditions, etc. Linguists claim that a rich heritage pertaining to the making of terminology has not got due consideration so far.

The scholars who studied the problems of terms in the second half of XIX century didn't use the term "terminology" but made use of the terms "elements of scientific terminology), "scientific style" vs "incomplete scientific style", "scientific term" vs "with term characteristic features"; it is not without purpose the term to be a sound scientific term should have a life medium, scientific terminology and scientific style (Syzdyk, 2009, p. 518).

The beginning of the XX century is characterized as an important phase in the formation of Kazakh terminology. It involves the period from 1910 till the beginning of 1930. This period is specified by the training of qualified national specialists in education and science.

During the above - mentioned period scientific works by A. Baitursynov, Sh. Kudaiberdiev, Kh. Dosmukhameduly, Zh. Kuderin; M. Dulatov, M. Zhumabaev, Zh. Aimauytov, S. Kozhanov, E. Omarov, T. Shonanov, N. Torekulov have been published.

The representatives of Kazakh intelligentsia created the terms on the scientific basis meeting the requirements of society at that time. Besides, in conformity with the principles devised by Kazakh intelligentsia under the leadership of A. Baitursynov a terminological aspect acquired a national nuance.

Linguistic nature of terms, their history and ways of development originated from the research work done by A. Baitursynov, Kh. Zhubanov, Zh. Aimauytov, Kh. Dosmukhameduly, K. Kemengerov, S. Zhienbayev, N. Sauranbayev, S. Amanzholov, M. Balakayev. Nowadays topical problems of terminology have been considered in detail in the works of contemporary linguists. Working at high schools and institutions of higher education representatives of Kazakh intelligentsia designed course books, teaching aids, compiled terminological 
dictionaries that served as the basis of coining scientific terms in the Kazakh language. Their efforts were aimed at all - round educating of younger generation that would stand the test and demands of the time. We would lay special stress on the following authors and works in this respect: Eldes Omarov (course books on Geometry and Physics), Zhusipbek Aimauytov (course book on Psychology), Khalel Dosmukhamedov (course books on Anatomy, Animal Planet, Medicine), Kanysh Satbayev (course book on Algebra), Myrzhakyp Dulatov, Karim Zhalenov, Sultanbek Kozhanov (course book on Arithmetic), Zhumakhan Kuderin (course book on Plant-growing), Alimkhan Ermekov (course book on Analytical Geometry). These course books had been designed according to scientific terminological principles devised by A. Baitursynov.

National scientific terms were created in various fields of science, they were put into circulation, and scientific writing style was developed. However, that tendency didn't last for a long time. There was a period of "denationalization of science". Kazakh intelligentsia representatives made it a rule to write course books, teaching aids, learned articles in the conversational literary language.

Attempts on national term - creation activities are clearly seen in course books and teaching aids designed by Kazakh intelligentsia at the beginning of XX century. We can mention the following works: (The Language as means of communication) by A. Baitursynov, (The ABC), (Introduction to literature), (Geometry) by E. Omarov, (Animal planet), (Anatomy), (Natural History) by Kh. Dosmukhameduly (Psychology) Zh. Aimauytov, (Plant-growing) by Zh. Kuderin, (Pedagogics) by M. Zhumabayev, (Arithmetic) by M. Dulatov. Native Kazakh words as terms comprise approximately $90 \%$ of the contents of the above-mentioned course books and teaching aids. Borrowings do not top the native words by $10-15 \%$. The majority of the terms had been created taking into consideration the sound system peculiarities and the law of vowel harmony in the Kazakh language. That fact testifies that the term-formation sphere in Kazakh linguistics was given primary importance by Kazakh enlighteners.

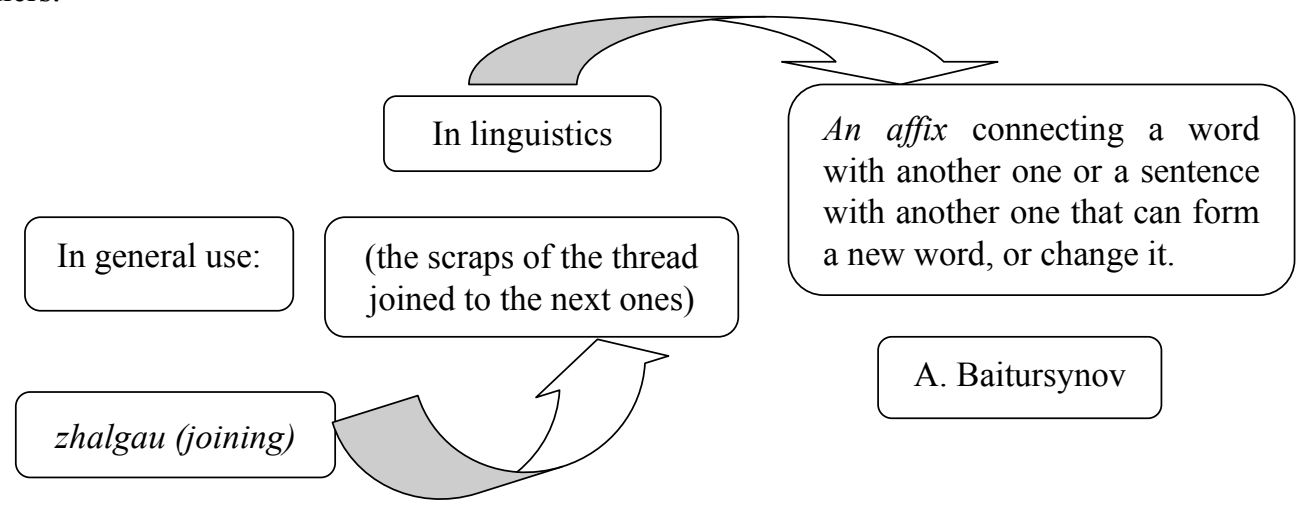

Figure 2. The model of scientific terms designed by A. Baitursynov (Terms created by Baitursynov)

A. Baitursynov's scholarly works exemplify that the representatives of Kazakh intelligentsia followed the right principles in creating terms. In the field of term-formation Akhmet Baitursynov adhered to two principles: First, to use every possible potential of the native language; second, to borrow items from the literary Russian language, especially, head-words. In the articles published in (Aikap) magazine, (Kazakh) newspaper and in the works (Teaching aid), (Language as a means of communication), (Language use), (Storytelling) A. Baitursynov used common native words as scientific terms. e.g. arip (letter), emle (orthography), dybys (sound), nokat (full stop), buyn (syllable), alippe (The ABC book), dauysty dybys (vowel), soz (word), soilem (a sentence), zhurnak (suffix), soz taptary (zat esim, etistik, syn esim, san esim, etc.), seven cases (atau septic, ilik septic, tabys septic, barys septic, zhatys septic, shygys septic, komektes septic), members of the sentence (bastauysh, bayandauysh, tolyktauysh, etc.), bunak, adis, etc. A. Baitursynov made a good use of internal potential of the Kazakh language in term-formation.

In creating the terms the basic meaning of the word can be used on the similarity phenomenon between the notion to be terminized and the word which was in the word stock of the language. e.g. the word "zhalgau (joining)) has the following meaning (the scraps of the thread joined to the next ones). In linguistics it can be used to denote an affix to connect a word with another one or a sentence with another one that can form a new word, or change it (Figure 2).

These examples testify that the term was coined by methaphorizing the primary meaning of the word. The following terms were coined by that method. e.g. rai (mood), shyrai (degrees of comparising), tubir (root), 
tarmac (line), bunak (tone group), teney (simile), zhurnak (suffix).

Alongside with it A. Baitursynov laid the foundation of the scientific terminology in Kazakh linguistics, literature, history and ethnography, general culture and methodology (Figure 3).

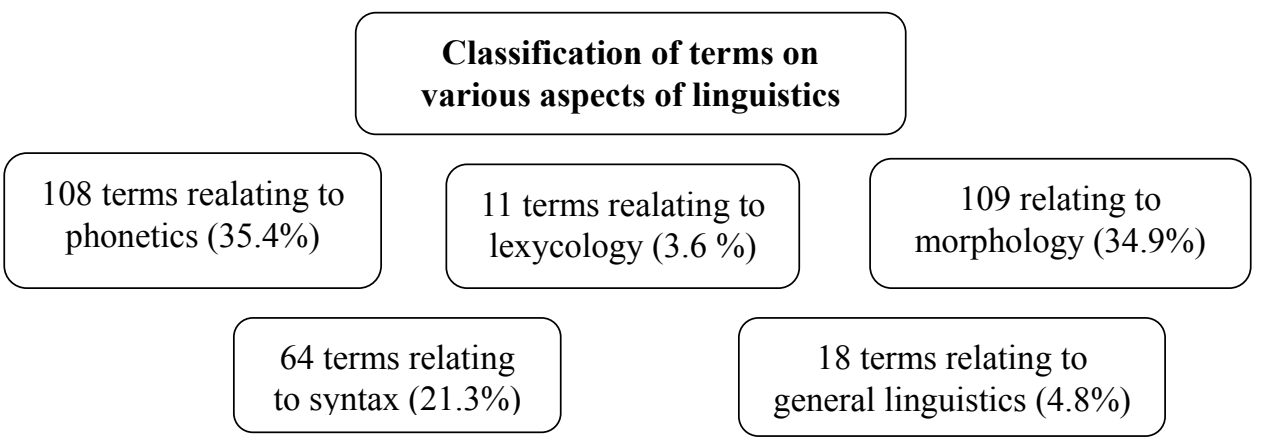

Figure 3. Vitality of terms created by A. Baitursynov

One of the published works during the period under discussion is the first course book in Biology (Plant growing) designed by Zhumakhan Kuderin (Kuderin, 1993). This book was published in Arab characters in Moscow (1927), in Latin characters in Qyzylorda (1930). It is the first book in plant-growing which was written in the Kazakh language and is still popular with scholars.

The book "Plant-growing" by Zhumakhan Kuderin published in 1927 hasn't lost its topicality so far. It is still a valuable manual in popularizing knowledge on plant planet among people.

There are about 300 Kazakh terms created from Kazakh names of plants. For instance, such terms as analyk, atalyk, tukymdyk, tostagansha etc., were formed by morphologic method, the terms analyktyn moiny, analyktyn auzy, agashtyn suiegi etc., were formed by analytical method, buyn, taramys, tugyr, tap etc., were formed by being transformed common words of everyday use into terms. These examples testify that techniques of word formation in the Kazakh language were widely used. Nowadays most of these terms comprise the terminology stock in plant growing.

The creation of terms by using the above - mentioned method could be found in the works by the authors at the turn of the XX century. For instance, in a "Manual on Arithmetic" by Sultanbek Kozhanov published in Tashkent (1924), we can encounter such terms as, darezhe (degree), tubir (root), syr (property), durkin (period), in "Pishindeme" (Geometry) by Eldos Omarov in Qyzylorda (1928), tuin (theorem), kar (cathetus), pishin (figure), kiya (diagonal), oris (radius), ore (diameter), saty (table), and in "Pedagogics" by Magzhan Zhumabaev published in Tashkent (1923), abai (being carefull), aser (influence), adet (habit), es (memory), khiyal (imagination), zhiger (will power).

The coursebooks and teaching aids published during the above - stated period played a great role in the coining of national terminology (Zhumabayev, 1992, p. 160).

Kh. Dosmukhameduly-being a brilliant scholar wrote more than 40 articles and 20 books on Medicine, Zoology, Biology, History, Language, Literature etc., It is the duty of next generation to collect all of them, to study his theoretical and scientific works, practical considerations and to evaluate the contribution made by him into the development of Kazakh linguistics.

Kh. Dosmuhameduly translated the following works into Kazakh: "Natural history", "Animals", "Anatomy", "Health care", "The stories on human bodies and its functions: by U. Vagner.

Kh. Dosmuhameduly left a rich scientific heritage. He was a disciple of Nobel Prize winner academician I. P. Pavlov and was held in respect by outstanding scholars like: V. V. Radlov, V. V. Bartold, Boduen de Courteney.

Carefully studying scientific works by European works he had created "Native terminology stock" in the Kazakh language and designed new good course books.

Reasoning on coining scientific terms Kh. Dosmuhameduly claimed "it's better to choose the native Kazakh words as much as possible", "to make scientific terms be comprehensible". Alongside with this he also stated that "it is impossible to lead living without borrowings", "we should borrow the words from the word stock of civilized nations to increase the amount of words in mother tongue". This proposal has been neglected by some contemporary scholars who adhere to purism. 
In Zh. Aimauytov wrote a course book 1924 "Guide on education" dedicated to pre-service and in-service teachers. In 1926 he wrote two course books: "Phsycology" and "The system of inner world and spheres of art". In 1929 he wrote the following books: "The ways of comprehensive training", "A new village", "How to eliminate illiteracy?" The terms used in Zh. Aimauytov's course book "Phsycology" revealed the potential of Kazakh term coining. This course book was written in good scientific style and according to scholars can be considered a guide to further study in the field of terminology (Aimauytov, 1998, p. 448)

\section{Discussion}

The policy of the scientific linguistic school that was set up on national basis in the XX century had been changed. It is a well-known fact that the representatives of Kazakh intelligentsia had a definite opinion on term coining. The Kazakh language was not considered as a passive one for A. Baitursynov created terms on language and literature, culture, policy and social relations on the basis of a native language. The same was done by Zh. Kuderin on plant growing. Many authors investigating the field of terminology made use of native words in coining terms. At that period of time experts in linguistics created terms related to science and technology progress using the national word stock.

We have studied the stages of terminology development, the peculiarities of term coining to define the present state of terminology system. It enables us to compare the past and the present in the field of terminology. The evaluation of the situation can be possible due to relying on the judgment of the representatives of Kazakh intelligentsia on differences and similarities, continuity and continuation of traditions in the field of scientific language that took place in the thirties.

First, according to Sh.Kurmanbaev, Kazakh enlighteners and linguists under the leadership of A. Baitursynov laid the foundation of national terminology stock (Kurmanbaiuly, 2014, p. 55). Nowadays hundreds of terms in different fields of science are still in active use.

It is worth mentioning some of them. e.g.: bayandama (talk), sogis (reprimand), ugym (notion), eritindi (solution), etc. These terms were used even in the twenties in Kazakh terminology system.

Second, in 1990s there was a fresh start in the field of term coining and linguists resorted to term - formation experience of Kazakh intellectuals of the past. Some terms used in 1930s later fell into disuse but in the last ten-fifteen years a few of them have come into use. For instance: hattama (minutes), aryz (application), adis (method), kenes (advice), zharnama (advertisement). It manifests continuity of traditions in linguistics.

Third, at present we adopt the experience of the first Kazakh intelligentsia in organizational and research work in the field of terminology. Terminological commission (5-6 experts) headed by Akhmet Baitursynov did a great job in coining Kazakh terms and putting them into use. They compiled specialist dictionaries of terms and made them available to the public.

In a nutshell, Akhmet Baitursynov made a great contribution to development general linguistics, to the formation of scientific language and Kazakh terminology.

\section{Conclusion}

Kazakh intellectuals of the past headed by Akhmet Baitursynov did their best to compensate the deficiency for course books on some core subjects and to forming a national scientific language and its terminology at due time. It entailed the creation of new terms, speech formulas, phrases.

Many new terms in various fields of science were published in mass media first, and then became the object of discussion among scholars and after that they were approved and confirmed by the decision of State terminology commission. The terms were used in designing Kazakh language course books in various spheres of science, scientific - technical literature that were to be used by the students in higher education establishments. These course books published in large circulation in Kazakh contributed to the development of scientific style.

The scientific terminology of every nation is formed on the basis of its national word stock. The creation and development of scientific terminology depend on the situation of national economy, lifestyle, writing styles, progress of science and technology, extra linguistic factors. Creation of scientific terminology is closely connected with the forming of a definite field of science.

Nowadays the Kazakh language has an official status and the term formation tendency has much in common with that one which took place at the beginning of the XX century (Syzdyk, 2009, p. 518; Kaidarov, 2008, p. 343; Aitbayev, 1997, p. 240; Mazhitaeva, 2000, 2007, p. 234; Kurmanbaiuly, 2008, 2014, p. 55).

Overwhelming amount of scientific technical terms consists of borrowings and it is characteristic not only for Kazakh language, it does not mean that borrowings should comprise the majority of terms in Kazakh 
terminology system (Mazhitaeva, 2014, p. 234; Popova, 2012).

The language that includes only borrowings and being not flexible to create terms cannot be considered a rich, versatile one. The conversion of such language into scientific language is also doubtful. Experts, language users in various fields of national economy are responsible for the forming of scientific language and terms in the national language. The process of Kazakh terminology creation should be investigated in close relation to the development of the history of science. Linguistic and extra linguistic factors that affect term formation should also be given thought (Conklin \& Lourie, 1983).

The present study has shown how the principles of term creation developed by Kazakh intelligentsia in the past have become the basis of further research work in the field of linguistics.

\section{Conflict of Interests}

The author(s) declare that the present paper has no competing interests.

\section{References}

Aimauytov, Zh. (1998). Psychology (p. 448). Almaty.

Aitbayev, U. (1997). The Kazakh word (Fundamentals of Kazakh terminology) (p. 240). Almaty.

Baitursynov, A. (2003). Introduction to literature (p. 208). Almaty: Atamura.

Blinova, O. I. (1981). Term and its motivation. Terminology and standard of speech (pp. 45-58). Moscow.

Conklin, N. F., \& Lourie, M. A. (1983). A Host of Tongues. Language Communities in the United States. NewYork.

Danilenko, V. P. (1977). Russian terminology. Moscow.

Dosmukhameduly, Kh. (1991a). Alaman (The Public) (p. 176). Almaty: Native language.

Dosmukhameduly, Kh. (1991b). The rule of vowel harmony in Kazakh-kyrgyz languages (p. 97). Almaty: Native Language.

Felde, O. V. (2010). Professional popular speech as a linguistic phenomenon. Terminology and knowledge. Proceedings of II International symposium (pp. 71-76). Moscow: Publishing center "Azbukovnik".

Golovin, B. N. (1973). On some proofs of being terminized of word combinations. Lexis, terminology, styles. Gorkii; Golovin B.N. Types of term systems and the basis of their discrimination. The term and the word. Gorkii.

Grinev, S. V. (1993). Introduction to the science of terminology (p. 309). Moscow.

Grinev-Grinevich, S. V. (2008). The science of terminology: Course book for students of higher education institution (p. 304). Moscow: Publishing center "Academy".

Kaidarov, A. (2008). New view on terminology of the Kazakh language (p. 343). Almaty.

Kuderin, Zh. (1992). Plant-growing. Almaty: Rauan.

Kurmanbaiuly, Sh. (1999). Kazakh lexis Terminalogization tendency (p. 55). Abstract of diss... doctor of science (philology). Almaty.

Kurmanbaiuly, Sh. (2008). Alash and science of terminology (Kazakh terminology at the beginning of the XX century. 1910-1930) (p. 240). Almaty.

Kurmanbaiuly, Sh. (2014). Sources of terminological stock formation and ways of term formation (p. 238). Almaty.

Leichik, V. M. (1989). Subject, methods and structure of terminology studies. Abstract of diss...doctor of science (philology). Moscow.

Lotte, D. S. (1969). The basis of the formation of scientific - technical terminology. Moscow.

Mazhitaeva etc. (2014). On The Problem of Loan Terms in Kazakh Terminology. Life Sci. J., 11(4S). Retrieved from http://www.lifesciencesite.com/lsj/life1104s/065_23816life1104s14_365-369.pdf

Mazhitayeva, Sh. (2000). Kazakh literary language in the middle of the twentieth century. Abstract of diss... doctor of science (philology) (p. 53). Almaty.

Mazhitayeva, Sh. (2007). Kazakh literary language at the beginning of the XX century (p. 234). Karaganda. 
Mishlanova, S. L. (2003). Terminology of XXI century: History, tendencies, perspectives. Philological bulletin, 3.

Petushkov, V. P. (1972). Linguistics and terminology. Terminology and norm (pp. 102-116). Moscow.

Petushov, V. P., Sorokoletov, F. P., \& Sergeev, V. I. (1976). On the ways of defining the meaning of terms in dictionaries. Problems of defining terms in dictionaries of different types. Leningrad.

Popova, M. (2012). The theory of terminology. Veliko Tyrnova: Znak.

Reformatsky, A. A. (1968). A term as a lexical system item of a language. Problems of structural linguistics (pp. 103-125). Moscow.

Shelov, S. D., \& Leichik, V. M. (2001). Terminology norm in the coverage of Russian linguists in 70s - 80s of the XX century. Terminological bulletin: Collection of scientific works, 1, 7-18.

Syzdyk, R. (2009). Extracts from scientific thoughts (p. 518). Almaty.

Tatarinov, B. A. (1996). The theory of terminology. The theory of terms: History and contemporary state (Vol. 1). Moscow.

Tatarinov, V. A. (1995). The history of home terminology: The tendencies and methods of terminological study. Moscow.

Vinokur, G. O. (1939). On some phenomena of word formation in Russian technical terminology (Vol. 5). Moscow.

Volodina, M. N. (2013). Ueber Nationales und Internationales im Prozess terminologischer Nomination. Dynamik der Sprache(n) und der Disziplinen. Budapester Beitraege zur Germanistik. Schriftreihe des Germanistisches Instituts der Lorand-Eoetvoes-Universitaet (Vol. 70, pp. 217-222). ELTE Germanistisches Institut Budapest, Hungary.

Zhumabayev, M. (1992). Pedagogics (p. 160). Almaty: Mother tongue.

\section{Copyrights}

Copyright for this article is retained by the author(s), with first publication rights granted to the journal.

This is an open-access article distributed under the terms and conditions of the Creative Commons Attribution license (http://creativecommons.org/licenses/by/3.0/). 